\title{
ARTICLE OPEN The dichotomous and incomplete adaptive immunity in COVID-19 patients with different disease severity
}

\author{
Leiqiong Gao ${ }^{1}$, Jing Zhou ${ }^{1}$, Sen Yang ${ }^{2}$, Lisha Wang ${ }^{1}$, Xiangyu Chen ${ }^{1}$, Yang Yang ${ }^{1}$, Ren Li ${ }^{3,4}$, Zhiwei Pan ${ }^{1}$, Jing Zhao ${ }^{5}$, Zhirong Li ${ }^{1}$,
} Qizhao Huang ${ }^{6}$, Jianfang Tang ${ }^{1}$, Li Hu${ }^{1}$, Pinghuang Liu ${ }^{7}$, Guozhong Zhang ${ }^{5}$, Yaokai Chen (iD ${ }^{2}$ and Lilin Ye (iD)

The adaptive immunity that protects patients from coronavirus disease 2019 (COVID-19), caused by severe acute respiratory syndrome coronavirus 2 (SARS-CoV-2), is not well characterized. In particular, the asymptomatic patients have been found to induce weak and transient SARS-CoV-2 antibody responses, but the underlying mechanisms remain unknown; meanwhile, the protective immunity that guide the recovery of these asymptomatic patients is elusive. Here, we characterized SARS-CoV-2-specific B-cell and T-cell responses in 10 asymptomatic patients and 64 patients with other disease severity (mild, $n=10$, moderate, $n=32$, severe, $n=12$ ) and found that asymptomatic or mild symptomatic patients failed to mount virus-specific germinal center (GC) B cell responses that result in robust and prolonged humoral immunity, assessed by GC response indicators including follicular helper $T\left(T_{F H}\right)$ cell and memory $B$ cell responses as well as serum CXCL13 levels. Alternatively, these patients mounted potent virus-specific $\mathrm{T}_{\mathrm{H}} 1$ and $\mathrm{CD} 8^{+} \mathrm{T}$ cell responses. In sharp contrast, patients of moderate or severe disease induced vigorous virus-specific GC B cell responses and associated $T_{F H}$ responses; however, the virus-specific $\mathrm{T}_{\mathrm{H}} 1$ and $\mathrm{CD}^{+} \mathrm{T}$ cells were minimally induced in these patients. These results, therefore, uncovered the protective immunity in asymptomatic patients and also revealed the strikingly dichotomous and incomplete humoral and cellular immune responses in COVID-19 patients with different disease severity, providing important insights into rational design of effective COVID-19 vaccines.

Signal Transduction and Targeted Therapy (2021)6:113

; https://doi.org/10.1038/s41392-021-00525-3

\section{INTRODUCTION}

As of November 27, 2020, the ongoing pandemic of COVID-19, caused by SARS-CoV-2 infection, has led to over 60 million confirmed cases and over 1.4 million thousand deaths, according to WHO issued COVID-19 Weekly epidemiological update-24 November 2020-181. ${ }^{1}$ Thus far, no vaccines has been approved to prevent SARS-CoV-2 infection, albeit several types of vaccine candidates reported at different clinical trial stages. ${ }^{2,3}$

The SARS-CoV-2 infected patients generally manifest diverse clinical symptoms, ranging from no symptoms to critical illness, which can be further categorized into four groups, including asymptomatic, mild, moderate, and severe. ${ }^{4-6}$ The adaptive immunity, encompassing humoral and cellular immune responses, is a key to clear a wide variety of viral infections, rendering patients recovered from viral diseases. ${ }^{7}$ In SARS-CoV-2 infection, both virusspecific B-cell mediated humor immunity and T-cell mediated cellular immunity have been implicated in recovered COVID-19 patients. ${ }^{8-12}$ Notably, in asymptomatic patients, SARS-CoV-2-specific IgGs were minimally produced and poorly maintained, ${ }^{13}$ in contrast, patients of severe disease mounted potent virus-specific lgG responses. ${ }^{14-16}$ However, the immune mechanisms underlying the dichotomous virus-specific lgG immune responses between asymptomatic or severe symptomatic patients are not well understood. Thus far, it also remains unknown whether virus-specific $T$ cell immune responses are effectively induced to protect asymptomatic patients from progressing to severe disease. To characterize virus-specific B- and Tcell immune responses in recovered COVID-19 patients with different degrees of clinical symptoms will provide important insights into understanding the protective immunity for COVID-19, which will lay the foundation for rationally designing effective vaccines against SARS-CoV-2 infection.

\section{RESULTS}

Subjects

To explore the adaptive immune responses in recovered COVID-19 patients with different clinical symptoms, we organized a cohort of 64 adult patients (31 males and 33 females), including asymptomatic ( $n=10)$, mild $(n=10)$, moderate $(n=32)$, severe $(n=12)$ symptoms, admitted in Chongqing Public Health Center, China (Table 1, Supplementary Table S1). All the patients were positive with SARSCoV-2 nucleic acid testing. The clinical and pathological characteristics were summarized in Table 1. The disease severity was stratified into asymptomatic, mild, moderate, and severe based on the national diagnosis and treatment guideline of COVID-19 (7th edition) in China ${ }^{6}$ (Supplementary Table S1). The admission date were from $02 / 06 / 2020$ to $04 / 24 / 2020$ and the average duration of hospitalization was 19 (7-51) days. The peripheral blood mononuclear cells

\footnotetext{
${ }^{1}$ Institute of Immunology, Third Military Medical University, Chongqing, China; ${ }^{2}$ Chongqing Public Health Medical Center, Chongqing, China; ${ }^{3}$ State Key Laboratory of Veterinary Biotechnology, Harbin Veterinary Research Institute, Chinese Academy of Agricultural Sciences, Harbin, Heilongjiang, China; ${ }^{4}$ College of Veterinary Medicine, Northeast Agricultural University, Harbin, Heilongjiang, China; ${ }^{5}$ Key Laboratory of Animal Epidemiology of the Ministry of Agriculture, College of Veterinary Medicine, China Agricultural

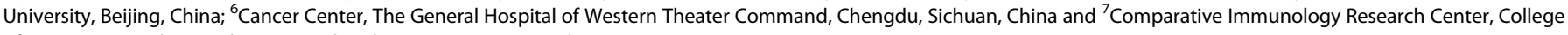
of Veterinary Medicine, China Agricultural University, Beijing, China

Correspondence: Guozhong Zhang (zhanggz@cau.edu.cn) or Yaokai Chen (yaokaichen@hotmail.com) or Lilin Ye (yelilinlcmv@tmmu.edu.cn)

These authors contributed equally: Leiqiong Gao, Jing Zhou, Sen Yang, Lisha Wang
}

Received: 27 November 2020 Revised: 27 January 2021 Accepted: 4 February 2021

Published online: 08 March 2021 
Table 1. Characteristics of patients in this study

\begin{tabular}{|c|c|c|c|c|c|c|}
\hline & $\begin{array}{l}\text { All } \\
(n=72)\end{array}$ & $\begin{array}{l}\text { Healthy } \\
(n=8)\end{array}$ & $\begin{array}{l}\text { Asymptomatic } \\
(n=10)\end{array}$ & $\begin{array}{l}\text { Mild } \\
(n=10)\end{array}$ & $\begin{array}{l}\text { Moderate } \\
(n=32)\end{array}$ & $\begin{array}{l}\text { Severe } \\
(n=12)\end{array}$ \\
\hline Age (years, median, IOQ) & $67(19-74)$ & $30.5(25-38)$ & $21(19-56)$ & $30(19-56)$ & $39.5(20-67)$ & $65(43-74)$ \\
\hline \multicolumn{7}{|l|}{ Gender } \\
\hline Female & 37 & 4 & 4 & 6 & 17 & 6 \\
\hline Male & 35 & 4 & 6 & 4 & 15 & 6 \\
\hline Onset of discharge to sample collection (days, median, IOQ) & $14(10-17)$ & & $13.5(10-15)$ & $13.5(10-14)$ & $13.5(10-16)$ & $14(14-17)$ \\
\hline Duration of hospitalization & $19(7-51)$ & & $24(12-51)$ & $22(12-31)$ & $16.5(7-29)$ & $26(13-34)$ \\
\hline Hospital admission date (medium IQR) & $\begin{array}{l}2020 / 2 / 18 \\
(2020 / 2 / 06 \\
\text { to } \\
2020 / 4 / 24)\end{array}$ & & $\begin{array}{l}2020 / 3 / 28 \\
(2020 / 3 / 22 \\
\text { to } \\
2020 / 4 / 15)\end{array}$ & $\begin{array}{l}2020 / 4 / 09 \\
(2020 / 2 / 08 \\
\text { to } 2020 / 4 / 24)\end{array}$ & $\begin{array}{l}2020 / 2 / 13 \\
(2020 / 2 / 02 \\
\text { to } \\
2020 / 3 / 06)\end{array}$ & $\begin{array}{l}2020 / 2 / 21 \\
(2020 / 2 / 06 \\
\text { to } \\
2020 / 3 / 12)\end{array}$ \\
\hline
\end{tabular}

1. Continuous variables were shown as the median (interquartile range, IQR)

2. All of 64 COVID-19 patients were tested positive qPCR for SARS-CoV-2 virus RNA upon hospital admission. Patients were diagnosed as severe when meeting any one of the following conditions: (1) anhelation (RR $\geq 30 / \mathrm{min}$ ), (2) SpO2 $\leq 93 \%$, (3) $\mathrm{PaO} 2 / \mathrm{FiO} 2 \leq 300 \mathrm{mmHg}$ and (4) imageological diagnosis of significant progress (> $0 \%)$ in $24-48 \mathrm{~h}$. The moderate patients were diagnosed with respiratory symptoms, fever and imageological evidence of pneumonia

The mild patients were diagnosed with mild clinical symptoms and no imageological evidence of pneumonia. The asymptomatic patients were those without any clinical symptoms

(PBMCs) and sera were collected at 10 to 17-day post-discharge for all the patients. For asymptomatic patients, their PBMCs were harvested twice during the hospitalization.

Failure of SARS-CoV-2-specific GC B cell reaction in asymptomatic COVID-19 patients

By flow cytometry analysis, we found comparable proportions of $\mathrm{CD}^{+}, \mathrm{CD}^{+} \mathrm{T}$ cells, and $\mathrm{B}$ cells among PBMCs between patients with asymptomatic, mild illness, and healthy controls. However, moderate, and severe symptomatic patients exhibited a significant reduction in proportions of $\mathrm{CD}^{+}$and $\mathrm{CD}^{+} \mathrm{T}$ cells but a marked increase in frequencies of B-cells compared to healthy controls (Supplementary Fig. S1a-c), consistent with the observations in recent studies. ${ }^{12,17}$

The increase of total B cell compartment in recovered COVID-19 patients of moderate and severe illness likely indicated elevated SARS-CoV2-specific B cell responses. To test this hypothesis, we investigated $B$ cells specifically recognizing SARS-CoV-2 spike protein subunits, S1 and S2, both of which represent dominant antigens of SARS-CoV-2 to induce virus-specific B-cell responses. ${ }^{18,19}$ As expected, we noted remarkably increased S1/S2-specific B cells in recovered patients with moderate or severe symptoms compared to those in recovered patients of asymptomatic or mild illness (Fig. 1a, c). Coincident with these results, we also observed a substantial enhanced S1/S2-specific memory B cell population (IgD ${ }^{\text {low }} \mathrm{CD} 19^{+}$ $\mathrm{S}^{+} / \mathrm{S} 2^{+} \mathrm{CD} 27^{\mathrm{hi}}$ ) in patients with moderate (about $10 \%$ of $\mathrm{S} 1 / \mathrm{S} 2-$ specific B cells) or severe disease (about $25 \%$ of S1/S2-specific B cells), while memory B-cell fractions were scarcely shown in patients of asymptomatic or mild illness (Fig. 1b, d). In line with these results, we found S1/S2-specific lgG titers highest in sera of patients with moderate or severe disease, while lowest in sera of patients with asymptomatic or mild disease, consistent with the results observed in recent studies $^{14}$ (Fig. 1e, f).

Germinal center (GC) reaction in B-cell follicles within secondary lymphoid tissues gives rise to long-lived memory $B$ cells and bonemarrow resident plasma cells capable of constitutively secreting antigen-specific lgGs, which strictly depends on the help provided by cognate follicular helper $T\left(T_{F H}\right)$ cells. ${ }^{20,21}$ Since lymphoid tissues are inaccessible from recovered COVID-19 patients, we take advantage of measuring circulating $\mathrm{T}_{\mathrm{FH}}\left(\mathrm{CT}_{\mathrm{FH}}\right)$ cell and chemokine CXCL13 to reliably indicate the magnitude of ongoing GC responses. ${ }^{22,23}$ In support of the aforementioned results, we noted a PD1 ${ }^{\text {hi }}$ CXCR5 ${ }^{\text {hi }} \mathrm{CT}_{\mathrm{FH}}$ population accounting for about $15 \%$ of total $\mathrm{CD}^{+}{ }^{+} \mathrm{T}$ cells in COVID-19 patients recovered from severe disease, about $5 \%$ in patients of moderate disease, while such population was almost unappreciable in counterparts with asymptomatic or mild disease (Fig. 1g, h). Likewise, we observed the minimal CXCL13 concentration in sera from recovered patients with asymptomatic or mild illness; In stark contrast, copious CXCL13 was detected in sera from patients recovered from moderate (average $415 \mathrm{pg} / \mathrm{ml}$ ) or severe disease (average $850 \mathrm{pg} / \mathrm{ml}$ ) (Fig. 1i). Further correlation analysis revealed the high relevance between S1/S2-specific IgG antibodies and total B-cell frequencies, CXCL13 concentration and frequencies of $\mathrm{CT}_{F H}$ (Fig. 2a-f). We also observed the high correlation between CXCL13 concentration and frequencies of $\mathrm{CT}_{\mathrm{FH}}$ (Fig. $2 \mathrm{~g}$ ).

Transient SARS-CoV-2-specific B cell response in asymptomatic individuals

Given the failure of inducing prolonged SARS-CoV-2-specific B-cell responses by asymptomatic or mild patients, we speculate whether these patients have mounted transient virus-specific B-cell responses during their hospitalization. To this end, we first analyzed S1- or S2specific B cell frequencies in their PBMCs at different time points during hospitalization. We found that the peak of S1/S2-specific B cell responses was induced at early stage (day 0-3) of hospitalization, which rapidly waned at the middle and convalescent stages (Fig. 3a, c). Concomitantly, we observed the similar dynamics of plasmablasts $\left(\mathrm{CD} 19^{+} \mathrm{CD} 20^{-} \mathrm{CD} 27^{\text {hi }} \mathrm{CD} 38^{\mathrm{hi}}\right.$ ) (Fig. 3b, d), which generally reflect the extrafollicular antibody responses during primary viral infection. ${ }^{12,24,25}$ In keeping with these observations, we also noticed the relatively higher S1- and S2- specific IgG titers at the middle stage (5-10 days post hospitalization) of hospitalization than those at both early ( $0-3$ days post hospitalization) and convalescent stages (more than 10 days after COVID-19 nucleic acid test shown negative) (Fig. 3e). Furthermore, we found nearly no $\mathrm{CT}_{\mathrm{FH}}$ population induced and CXCL13 secreted from early phase of hospitalization to convalescent stages (Fig. 3f-h). These data collectively revealed that SARS-CoV-2specific $B$ cell responses were only transiently induced in asymptomatic patients and sustained GC responses that give rise to longterm memory B cells and lgG-secreting plasma cells were likely absent in these patients, explaining the weak and short-term SARSCoV-2 specific lgGs in these patients reported most recently. ${ }^{14}$ Taken together, our results demonstrate that compared with potent and sustained SARS-CoV-2-specific GC B cell responses mounted in COVID-19 patients recovered from moderate or severe symptoms, asymptomatic or mild symptomatic COVID-19 patients only induced weak and transient SARS-CoV-2-specific B cell responses.

Potent SARS-CoV-2 specific cellular immune responses in COVID19 patients with asymptomatic disease

In addition to B-cell-associated humoral immunity, the cellular immunity mediated by $\mathrm{T}_{\mathrm{H}} 1$ and cytotoxic $\mathrm{CD}^{+} \mathrm{T}$ lymphocytes 
Gated on CD19+ cells

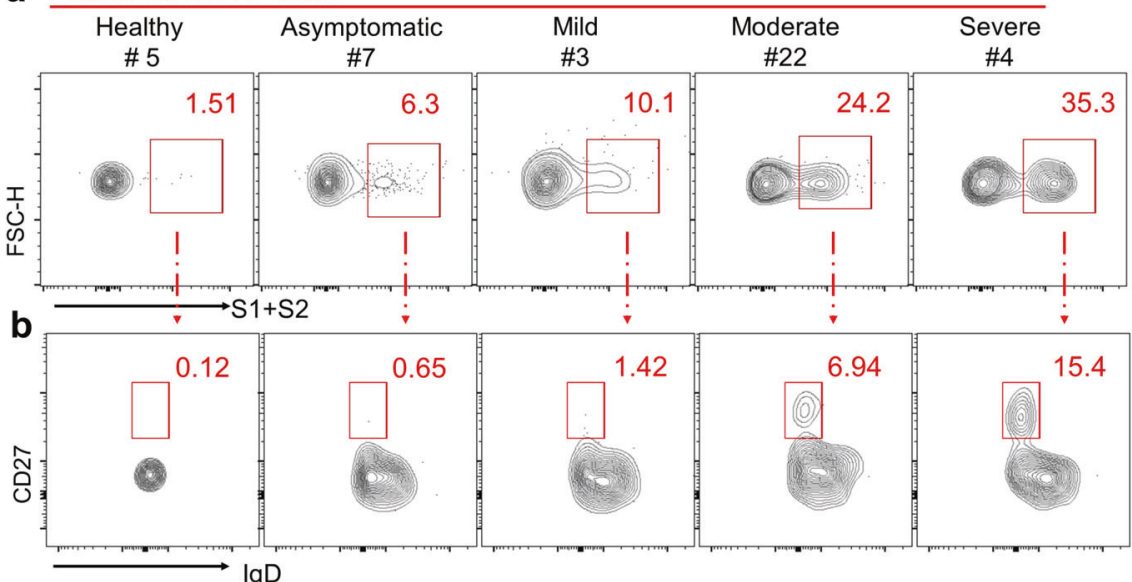

C

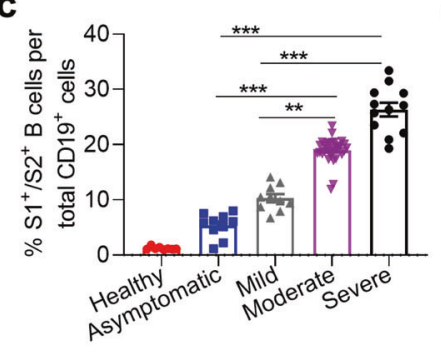

e

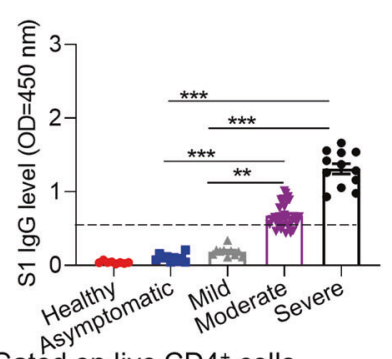

d

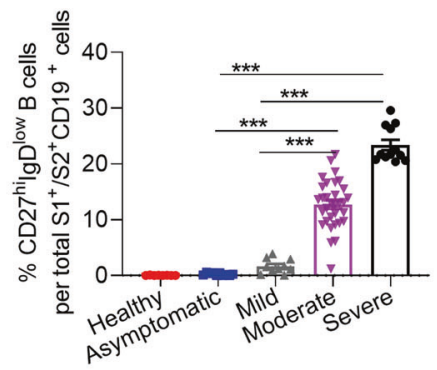

f

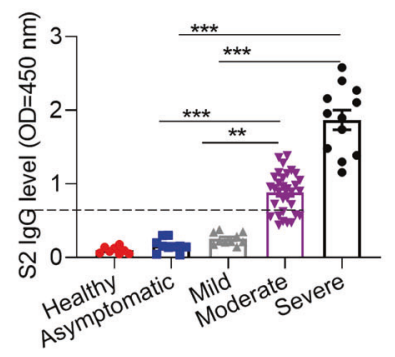

g Gated on live CD4 ${ }^{+}$cells
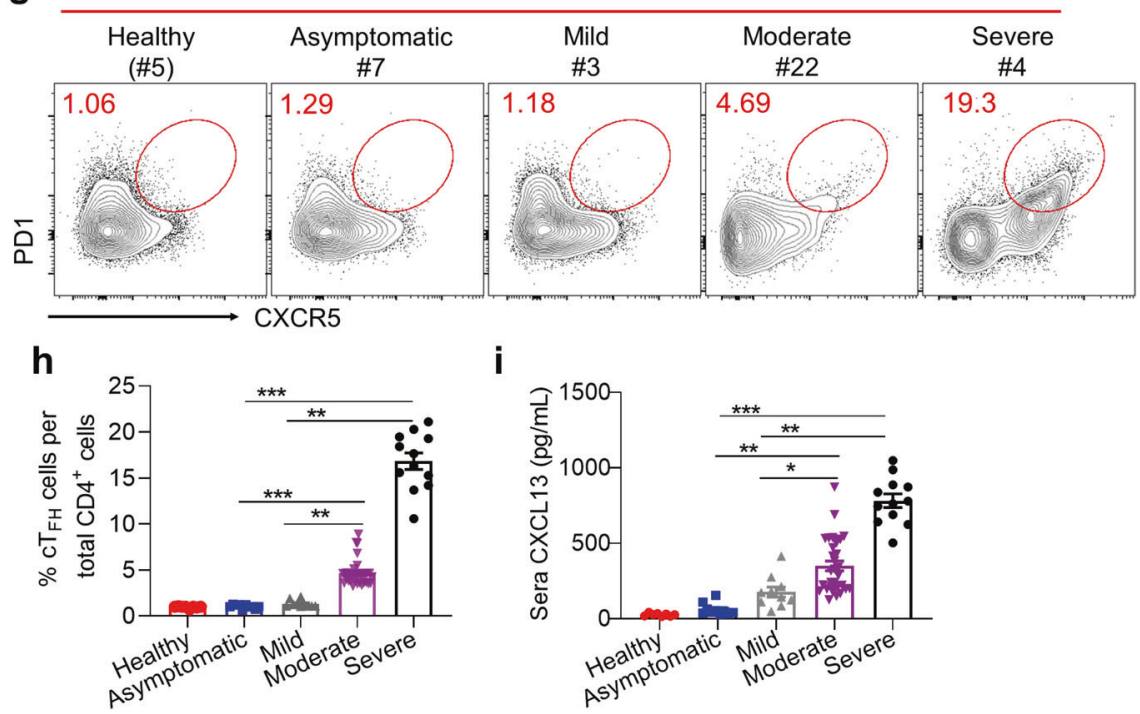

i

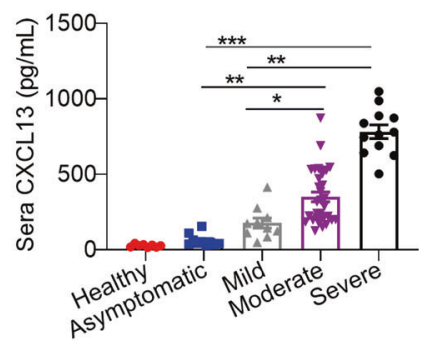

Fig. 1 Virus-specific B cell responses to SARS-CoV2 in COVID-19 patients with different severity. Samples of $\mathbf{a}, \mathbf{b}$ and $\mathbf{g}$ were from Healthy (\#5), Asymptomatic (\#7), Mild (\#3), Moderate (\#22), Severe (\#4). a FACS plot examples of SARS-CoV2 S1- or S2- specific B cells (S1 ${ }^{+} / \mathrm{S} 2^{+}$CD19 ${ }^{+}$) of live lymphocytes in PBMCs. b FACS plot examples of SARS-CoV2 S1- or S2- specific memory B cells (CD27 $7^{\text {hi }}$ IgD ${ }^{\text {low }}$ ), gated on S1 or S2 specific B cells $\left(\mathrm{S} 1^{+} / \mathrm{S} 2^{+} \mathrm{CD} 19^{+}\right)$shown in (a). c, d Percentages of S1 or S2 specific B cells (c), summarized from (a); and S1 or S2 specific memory B cells (d), summarized from (b), in COVID-19 recovered patients with different disease severity. e, $\mathbf{f}$ ELISA analysis of S1- and S2- specific lgG levels in convalescent-phase COVID-19 patients' sera with various groups. Dilution of 1:100 was used for serum samples. $\mathbf{g}$ FACS plot examples of $\mathrm{CT}_{\mathrm{FH}}$ $\left(\mathrm{PD} 1{ }^{\mathrm{hi}} \mathrm{CXCR} 5^{\mathrm{hl}}\right)$, gated on live CD4 ${ }^{+} \mathrm{T}$ cells. $\mathbf{h}$ The summarization of percentages of $\mathrm{CT}_{\mathrm{FH}}$ from $(\mathbf{g})$. $\mathbf{i}$ CXCL13 protein level in convalescent-phase COVID-19 patients' serum with various groups, measured by ELISA. Bars represent the mean \pm SEM. $P$ values were calculated based on Bonferroni of one-way ANOVA analysis. ${ }^{* *} p<0.0001$, ${ }^{* *} p<0.001$, and ${ }^{*} p<0.05$ 

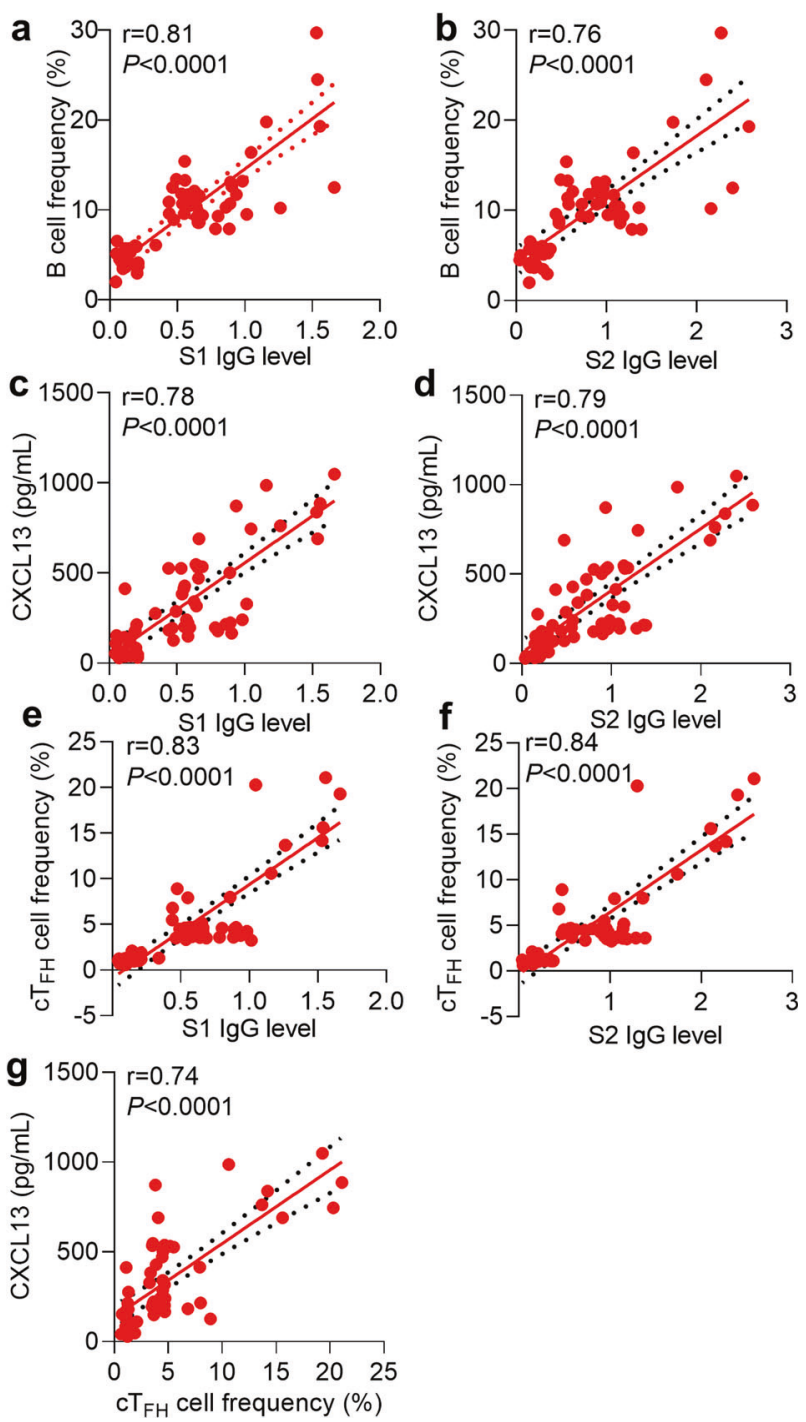

Fig. 2 Correlations between B cells frequency, serum CXCL13 concentration, CTFH cells frequency and S1- or S2- specific IgG levels. a, b Correlations between B cells frequency and S1- (a) or S2- (b) specific IgG levels. c, d Correlations between serum CXCL13 concentration and S1- (c) or S2- (d) specific lgG levels. e, f Correlations between $\mathrm{CT}_{\mathrm{FH}}$ cells frequency and S1- (e) or S2- (f) specific IgG levels. g Correlations between $\mathrm{CT}_{\mathrm{FH}}$ cells frequency and serum CXCL13 concentration. Statistical comparisons were performed using Spearman correlation analysis

also plays a critical role in the control of viral infection. ${ }^{7,26-30}$ The failure in the induction of a protective humoral immunity by COVID-19 patients recovered from the asymptomatic or mild disease may indicate an alternative strong cellular immunity that protected these patients from developing severe disease. To test this hypothesis, we sought to examine SARS-CoV-2-specific cellular immunity in recovered COVID-19 patients of different disease severity. To define the SARS-CoV2-specific CD4 ${ }^{+}$and $\mathrm{CD}^{+}$ $\mathrm{T}$ cells, we stimulated total PBMCs with SARS-CoV-2 dominant antigen (S1, S2, and nucleoprotein, N) cocktails for $48 \mathrm{~h}^{8}$ After antigen stimulation, we observed the background levels of IFN- $\gamma$ producing $\mathrm{CD}^{+}$and $\mathrm{CD}^{+}$T cells in PBMCs of healthy controls; in contrast, in asymptomatic patients, the proportions of IFN- $\gamma$ producing $\mathrm{CD}^{+}$and $\mathrm{CD}^{+}{ }^{+} \mathrm{T}$ cells were substantially enhanced (Fig. $4 a, b, e, f$ ), indicative of the specificity of our strategy in
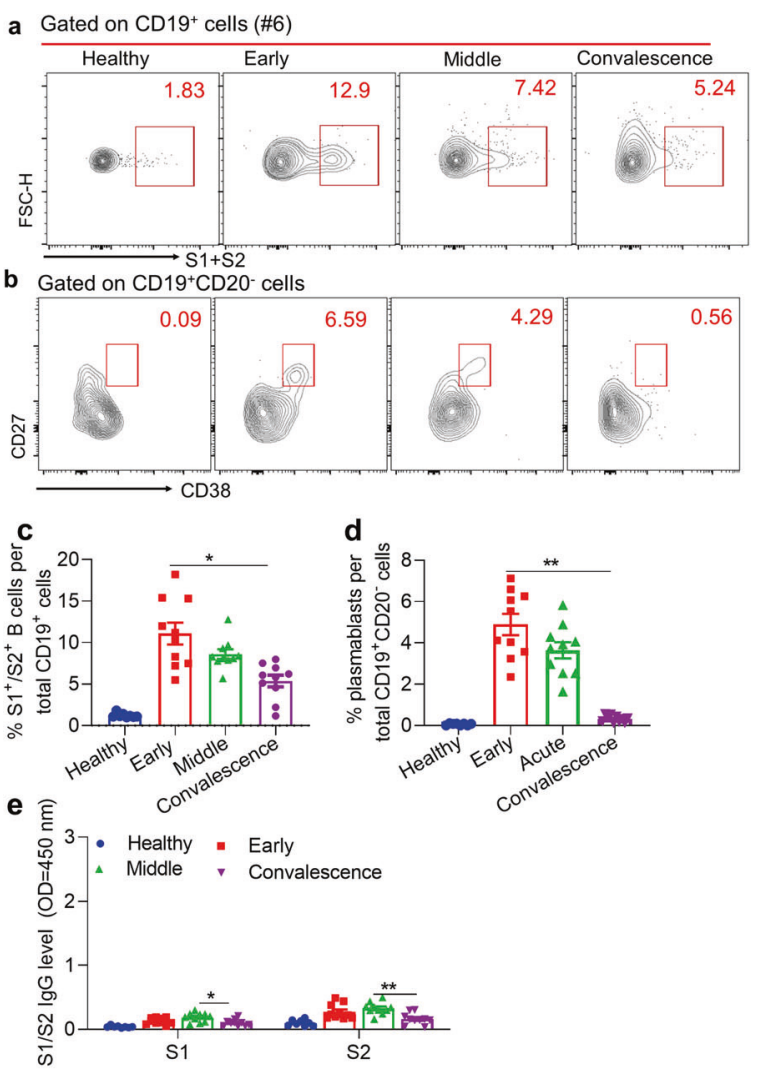

f Gated on live $\mathrm{CD}^{+}$cells (\#6)
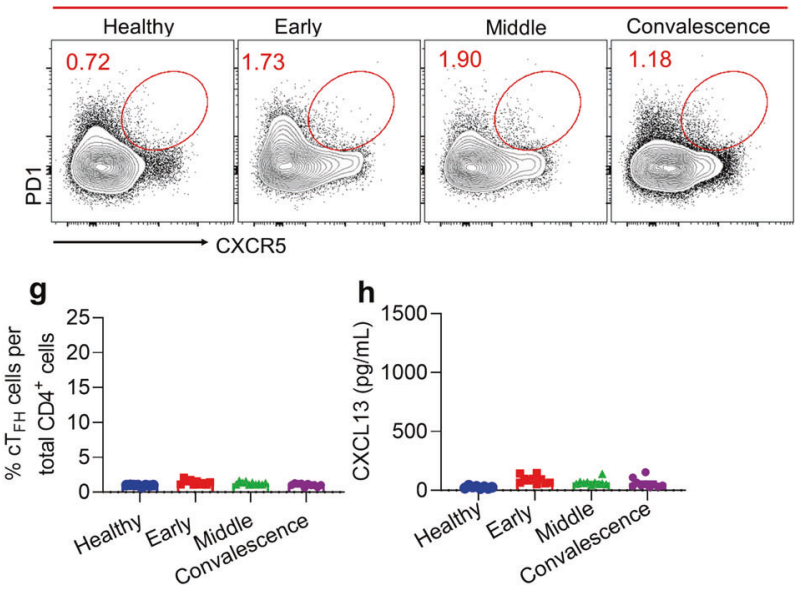

Fig. 3 Kinetics of virus-specific B cell responses to SARS-CoV2 in COVID-19 Asymptomatic patients. Sample of $\mathbf{a}, \mathbf{b}$ and $\mathbf{f}$ was from Asymptomatic (\#6). a, b FACS plot examples of SARS-CoV2 S1- or S2- specific $B$ cells and plasmablasts $\left(C D 19^{+} \mathrm{CD} 20^{-} \mathrm{CD} 27^{\mathrm{hi}} \mathrm{CD} 38^{\mathrm{hi}}\right)$ cells' percentage in early phase ( $0-3$ days post hospitalization), acute phase (5-10 days post hospitalization), convalescentphase, (more than 10 days after COVID-19 nucleic acid test shown negative) in the asymptomatic cohort. $\mathbf{c}$, d Percentages of S1- or S2- specific B cells (c), summarized from (a), and plasmablasts cells (d), summarized from (b), in the asymptomatic cohort. e Kinetics of S1- and S2- specific lgG levels in asymptomatic patients' serum, measured by ELISA. f FACS plot examples of $\mathrm{CT}_{\mathrm{FH}}$ cells' percentage of asymptomatic patients. g Percentages of $\mathrm{CT}_{\mathrm{FH}}$, summarized from (f). $\mathbf{h}$ Kinetics of CXCL13 level in asymptomatic patients' serum, measured by ELISA. Bars represent the mean \pm SEM. $P$ values were calculated based on Bonferroni of one-way ANOVA analysis. ${ }^{* * *} p<0.0001,{ }^{* *} p<0.001$, and ${ }^{*} p<0.05$ 
a Gated on live $\mathrm{CD} 4^{+}$cells
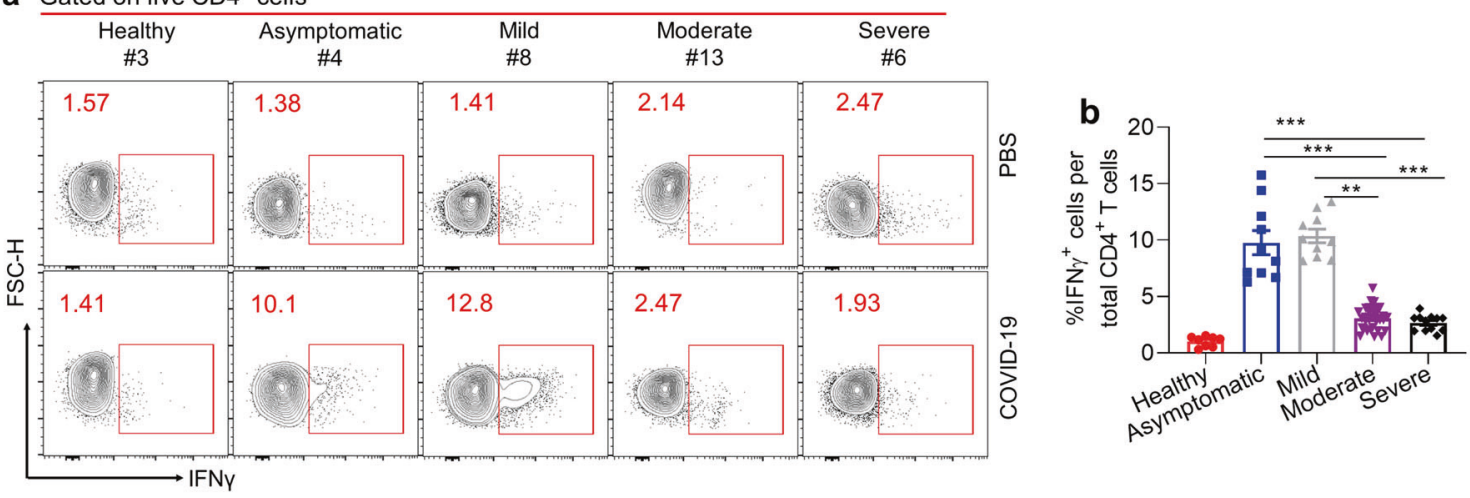

C Gated on IFNY+CD4+ cells
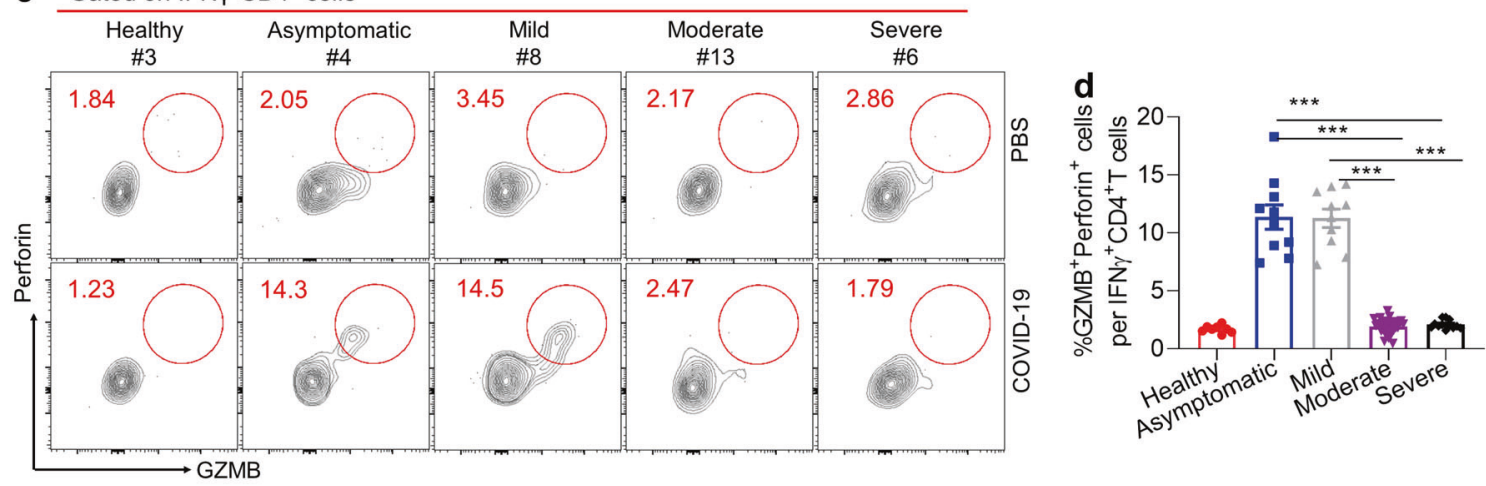

e Gated on live $\mathrm{CD} 8^{+}$cells
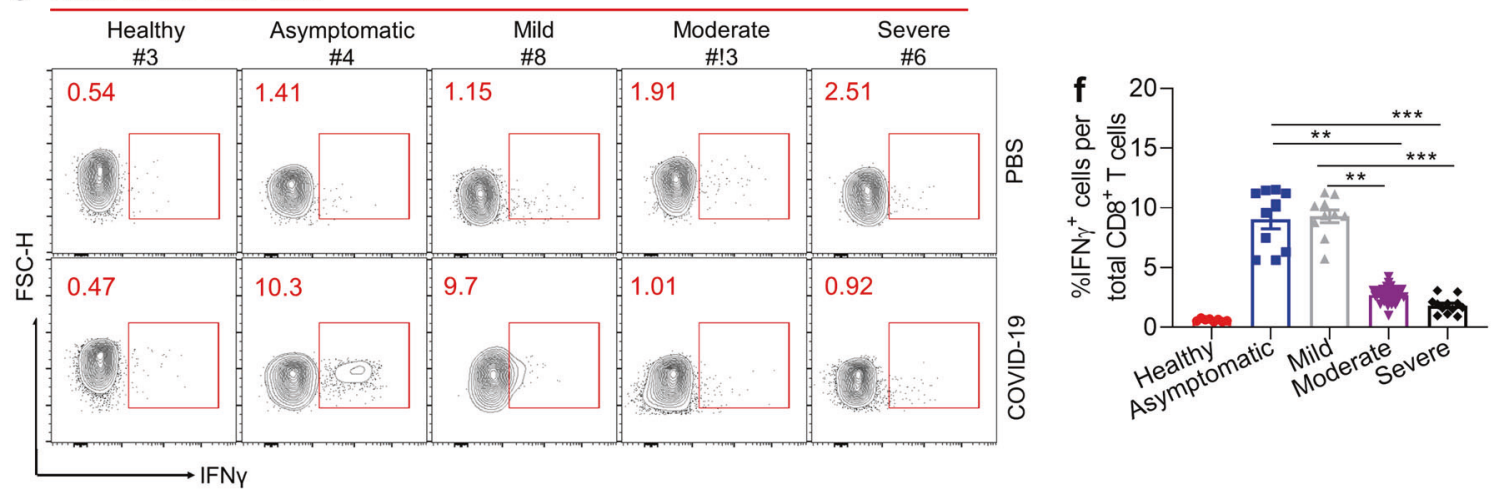

g Gated on IFNY+CD8 cells
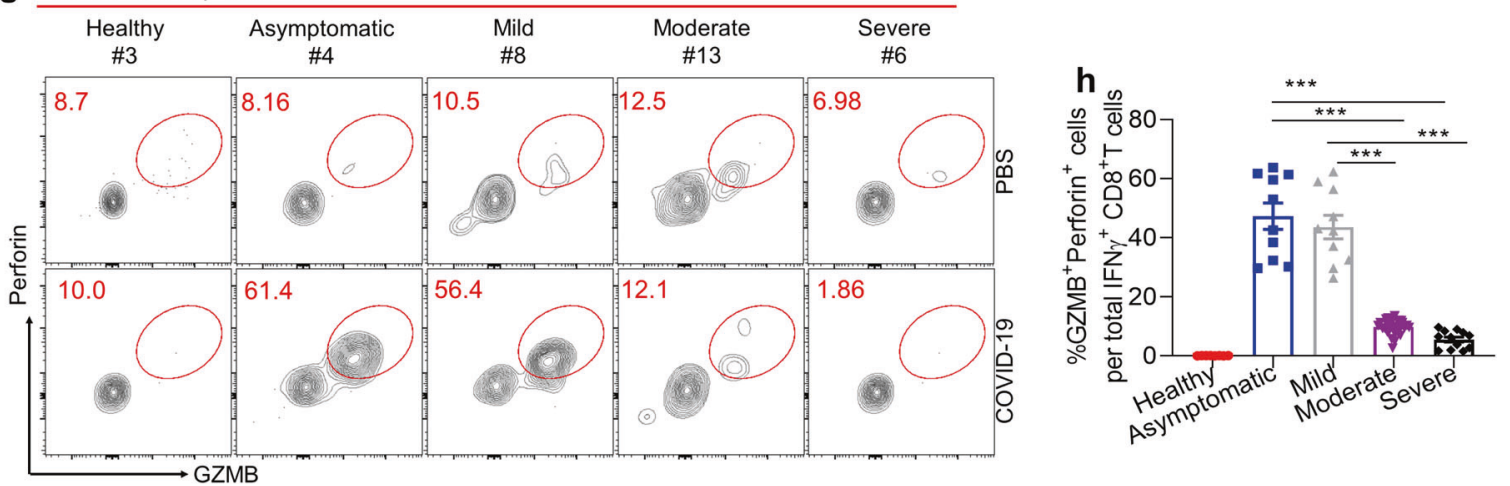

analyzing SARS-CoV-2-specific $\mathrm{CD}^{+}{ }^{+}$and $\mathrm{CD}^{+}{ }^{+} \mathrm{T}$ cells, which was further validated by stimulating these cells with SARS-CoV-2 derived peptides (Fig. S2a-d). ${ }^{31-34}$ Next, we compared the proportions of $T_{H} 1$ cells that secrete hallmark cytokine IFN- $\gamma$ in PBMCs among patients of different disease severity. Strikingly, we found the remarkably upregulated abundances of virus-specific
IFN- $\gamma$-secreting $T_{H} 1$ cells in asymptomatic or mild symptomatic patients relative to healthy controls; however, in patients with moderate or severe symptoms, they only exhibited background levels of virus-specific IFN- $\gamma$-producing $\mathrm{T}_{\mathrm{H}} 1$ cells post antigen stimulation as healthy control (Fig. 4a, b). Moreover, among those IFN- $\gamma$-producing $\mathrm{T}_{\mathrm{H}} 1$ cells, around $10 \%$ of them were found to 
Fig. 4 SARS-CoV2 specific CD4 ${ }^{+}$and $\mathrm{CD}^{+} \mathrm{T}$ cell responses in COVID-19 convalescent patients. PBMCs of healthy control ( $\left.n=8\right)$ and recovered COVID-19 patients $(n=64)$ were stimulated with SARS-CoV-2 dominant antigen (S1, S2 and nucleoprotein, N) cocktails for 44h, Golgi-Plug containing Golgi-stop and DNase were added into cell culture for another 4 h. Samples of a, c, e, and $\mathbf{g}$ were from Healthy (\#3), Asymptomatic (\#4), Mild (\#8), Moderate (\#13), severe (\#6). a FACS plot examples of IFN $\gamma^{+} \mathrm{CD} 4^{+} \mathrm{T}$ cells in total live $\mathrm{CD} 4^{+} \mathrm{T}_{\text {cells, gated on total live CD4 }}{ }^{+} \mathrm{T}_{\text {cells. }}$ b Bar graph shows the frequency of IFN $\gamma^{+} \mathrm{CD} 4^{+}$T cells in total $\mathrm{CD} 4^{+}$T cells after stimulation, summarized from (a). c FACS plot examples of $\mathrm{GZMB}^{+}$Perforin ${ }^{+} \mathrm{CD}^{+}{ }^{+} \mathrm{T}$ cells in total IFN $\gamma^{+} \mathrm{CD}^{+}{ }^{+} \mathrm{T}$ cells, gated on total live IFN $\gamma^{+} \mathrm{CD}^{+}{ }^{+} \mathrm{T}$ cells. d Frequency of GZMB ${ }^{+} \mathrm{Perforin}^{+} \mathrm{CD} 4^{+} \mathrm{T}$ cells in

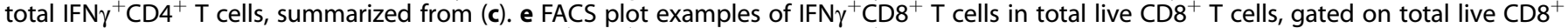
$\mathrm{T}$ cells. $\mathbf{f}$ Bar graph shows the frequency of IFN $\gamma^{+} \mathrm{CD}^{+} \mathrm{T}$ cells in total $\mathrm{CD} 8^{+} \mathrm{T}$ cells after stimulation, summarized from (e). $\mathbf{g}$ FACS plot examples of $\mathrm{GZMB}^{+}$Perforin ${ }^{+} \mathrm{CD} 8^{+} \mathrm{T}$ cells in total IFN $\gamma^{+} \mathrm{CD} 8^{+} \mathrm{T}$ cells, gated on total live IFN $\gamma^{+} \mathrm{CD} 8^{+} \mathrm{T}$ cells. $\mathbf{h}$ Frequency of $\mathrm{GZMB}^{+}$Perforin ${ }^{+} \mathrm{CD}^{+} \mathrm{T}$ cells in total IFN $\gamma^{+} \mathrm{CD}^{+} \mathrm{T}$ cells, summarized from $(\mathbf{g})$. Bars represent the mean $\pm \mathrm{SEM}$. $P$ values were calculated based on Bonferroni of one-way ANOVA analysis. ${ }^{* *} p<0.0001,{ }^{* *} p<0.001$, and ${ }^{*} p<0.05$

express cytolytic molecules granzyme B (GZMB) and perforin in patients of asymptomatic or mild illness, both of which have been found to be critical for the control of respiratory viral infection, ${ }^{35}$ while only around $2.5 \%$ of GZMB and perforin-producing $\mathrm{T}_{\mathrm{H}} 1$ cells in patients with moderate or severe disease (Fig. 4c, d). These results together indicated that virus-specific $\mathrm{CD}^{+}{ }^{+} \mathrm{T}$ cell responses was much biased toward to $T_{H} 1$ over $T_{F H}$ cells in asymptomatic or mild symptomatic patients, while vice versa in patients with moderate or severe disease. The cellular and molecular mechanisms underlying disease severity-dependent virus-specific CD4 ${ }^{+} \mathrm{T}$ cell differentiation in COVID-19 patients warrants further investigations.

Next, we assessed SARS-CoV-2-specific $\mathrm{CD}^{+}{ }^{+} \mathrm{T}$ cell responses in COVID-19 recovered patients. Be similar with the results of virusspecific $T_{H 1}$ responses, we found substantially induced virusspecific IFN- $\gamma$-producing $\mathrm{CD}^{+}{ }^{+} \mathrm{T}$ cells in asymptomatic or mild symptomatic patients as compared to healthy controls, whereas very limited IFN- $\gamma$-producing $\mathrm{CD}^{+}{ }^{+} \mathrm{T}$ cells in patients of moderate or severe symptoms (Fig. 4e, f). To further assess the cytolytic functionality of virus-specific $\mathrm{CD}^{+}{ }^{+} \mathrm{T}$ cells in COVID-19 patients, we first gated on the virus-specific IFN $-\gamma^{+} \mathrm{CD}^{+} \mathrm{T}$ cells, followed by measuring the frequencies of those cells capable of producing GZMB and perforin. We found that in asymptomatic or mild symptomatic patients, approximate $60 \%$ of IFN $-\gamma^{+} \mathrm{CD}^{+}$T cells simultaneously produced GZMB and perforin, whereas only $12 \%$ or $3 \%$ of IFN- $\gamma^{+} \mathrm{CD}^{+}$T cells were able to produce both cytolytic molecules in moderate or severe patients (Fig. $4 \mathrm{~g}$, h). These data, therefore, revealed that albeit the failure in mounting SARS-CoV-2specific humoral immunity, asymptomatic or mild symptomatic patients were able to induce a profound virus-specific cellular $\left(T_{H} 1\right.$ and $\mathrm{CD}^{+}{ }^{+}$cell) immunity. In sharp contrast, patients of moderate or severe disease were able to generate potent SARS-CoV-2specific humoral immunity, but they failed to induce effective virus-specific cellular immunity. The mechanisms underlying disease severity-associated dichotomous humoral and cellular immunity in COVID-19 patients need to be investigated in the future.

Early induced SARS-CoV-2 specific cellular immune responses in asymptomatic or mild individuals

Given the vigorous cellular responses detected in recovered COVID-19 patients of asymptomatic or mild disease, we wonder whether these patients have induced strong virus-specific T-cell responses at the early phase during their hospitalization. After SARS-CoV-2 antigen stimulation, we found that IFN- $\gamma$ producing $\mathrm{CD}^{+}$and $\mathrm{CD}^{+}{ }^{+}$cells was virtually increased at early stage (day $0-3$ ) of hospitalization in these asymptomatic patients, which were then well maintained at the middle (day 5-10) of hospitalization and convalescent stages (Fig. 5a, b, e, f). Concomitantly, we observed the similar dynamics of frequencies of $T$ cells capable of producing GZMB and perforin in these asymptomatic patients (Fig. $5 c, d, g, h$ ). These data collectively revealed that SARS-CoV-2-specific $\mathrm{T}_{\mathrm{H}} 1$ and $\mathrm{CD}^{+}$ $T$ cell responses were rapidly induced and sustained in asymptomatic patients.

\section{DISCUSSION}

Similar to most recent reports, ${ }^{13,14}$ our study found that anti-SARSCoV-2-antibodies were rapidly decay in asymptomatic or mild patients. We further found SARS-CoV-2-specfic B cell responses were only transiently induced in early infection phase in asymptomatic or mild patients. In keeping with this, sustained $\mathrm{GC}$ responses that give rise to long-term memory $B$ cells and IgGsecreting plasma cells were almost absent in these patients (Fig. 6). These results, therefore, explained the phenomenon that asymptomatic patients failed to generate and maintain a longterm SARS-CoV-2-specific lgG response.

In contrast to humoral immunity, the virus-specific $T_{H} 1$ and $\mathrm{CD}^{+} \mathrm{T}$ cell immune responses were rapidly induced and sustained in asymptomatic or mild symptomatic patients as compared to patients with moderate or severe disease, which presumably protect them from progressing to severe COVID-19 (Fig. 6). We also envision that the rapid and robust virus-specific $\mathrm{T}_{\mathrm{H}} 1$ and $\mathrm{CD}^{+} \mathrm{T}$ cell responses may effectively curtail the SARSCoV-2 replication, which results in the inefficient viral antigen production and therefore limits the GC reaction that critically depends on sufficient and prolonged antigen stimulation. Memory $\mathrm{T}$ cells induced by previous pathogens can protect the individual from re-infecting the similar pathogens with common epitopes and determine the clinical severity of subsequent infections. ${ }^{36}$ Besides SARS-CoV-1 and MERS-CoV, there are another four virus, which are endemically transmitted and cause the common cold (OC43, HKU1, 229E, and NL63). ${ }^{37}$ Recently studies found there exists cross-reactive $T$ cell recognition between circulating 'common cold' coronaviruses and SARS-CoV-2., 10 it is of great interest to examine whether the history of "common cold" coronavirus infection with pre-existing SARS-CoV-2 cross-reactive $\mathrm{T}$ cells could account for the clinically asymptomatic state in COVID-19 patients.

In summary, we revealed a striking dichotomous pattern of humoral and cellular immunity induced in patients of asymptomatic/mild or moderate/severe disease. The highly induced virusspecific $\mathrm{T}_{\mathrm{H}} 1$ and $\mathrm{CD}^{+} \mathrm{T}$ cell immune responses in asymptomatic or mild symptomatic patients may protect them from progressing to severe COVID-19 in the absence of humoral immunity, while potent virus-specific B cell responses likely account for the recovery of patients of moderate or severe COVID-19. These results highlighted the notion that SARS-CoV-2 infection generally does not induce complete both humoral and cellular immunity, suggesting that the induction of both optimal humoral and cellular immunity may be critical for an effective prophylactic vaccine to prevent SARS-CoV-2 infection.

\section{MATERIALS AND METHODS}

Human subjects

Blood samples from 8 healthy adult donors were obtained by the Institute of Immunology of Army Medical University, which has no contact with SARS-CoV-2 and test negative for SARS-CoV-2 RNA. These donors had no known history of any significant systemic diseases, including but not limited to, for example, 
a Gated on live $\mathrm{CD} 4^{+}$cells (\#3)
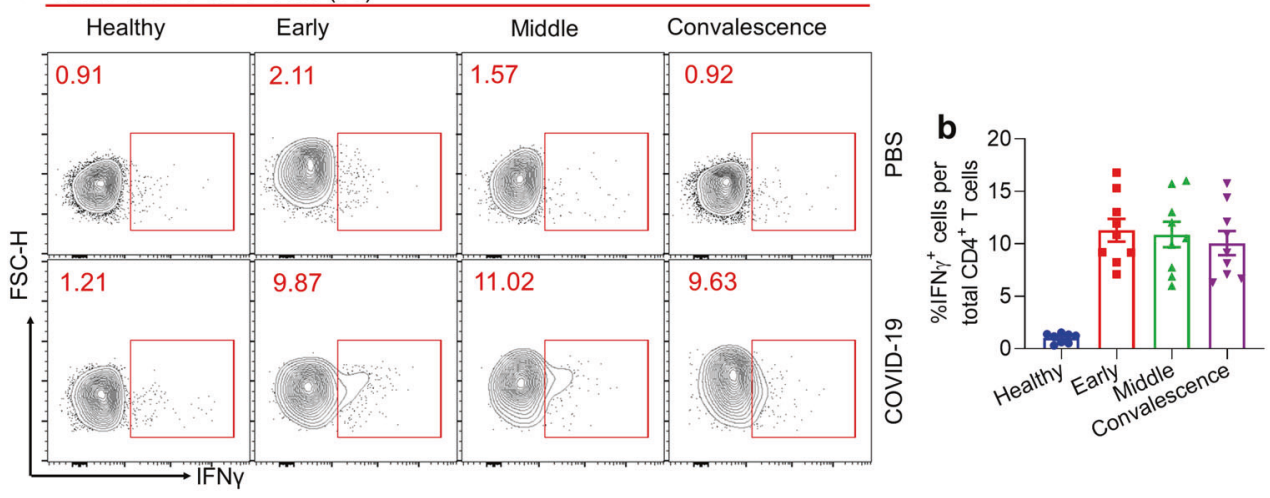

C Gated on IFNY+CD4+ cells (\#3)
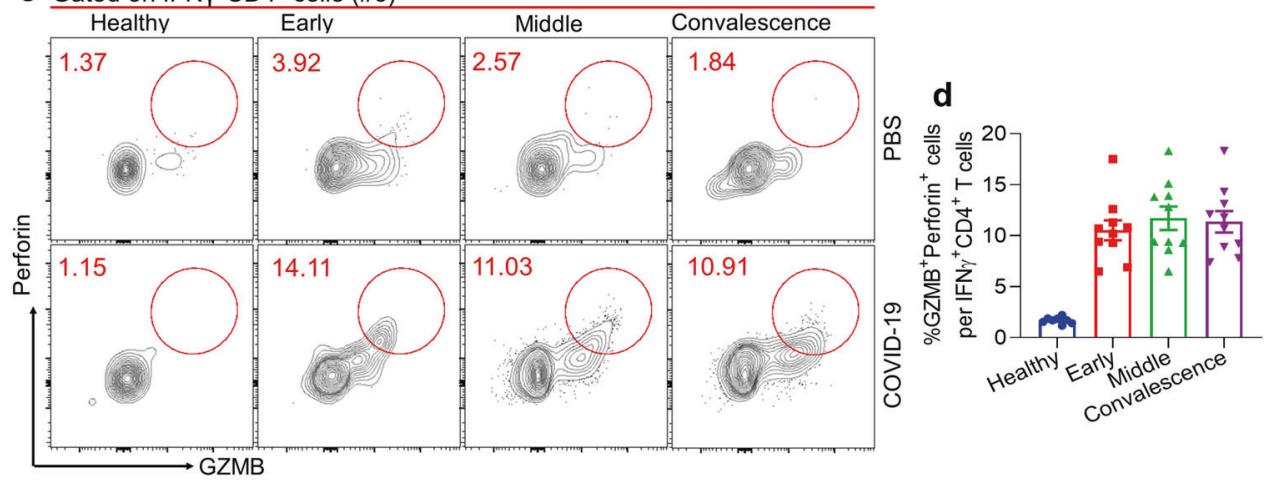

e Gated on live CD8 ${ }^{+}$cells (\#3)
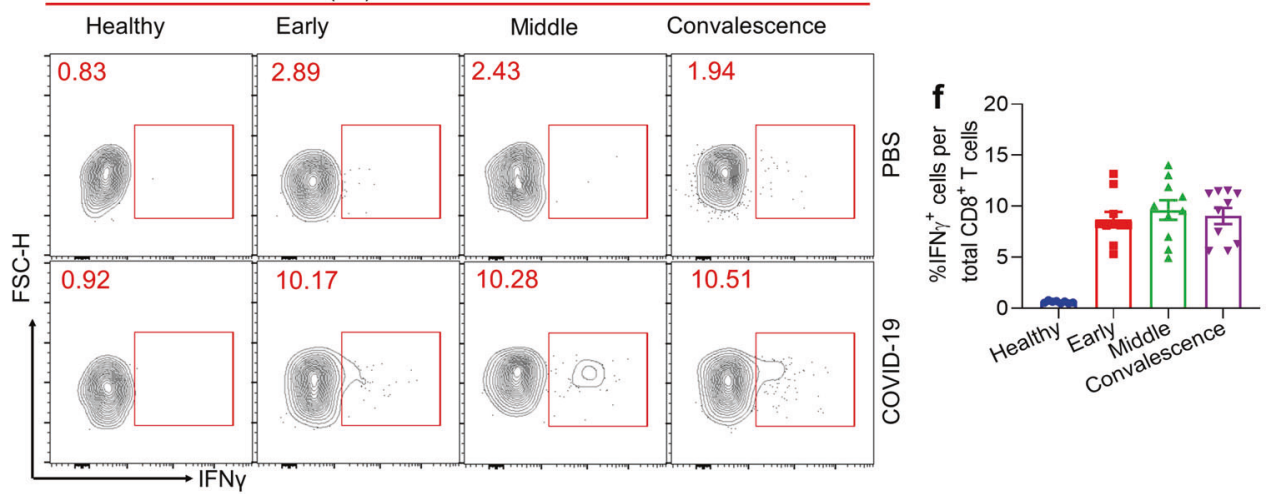

g Gated on IFNY ${ }^{+} \mathrm{CD} 8^{+}$cells (\#3)

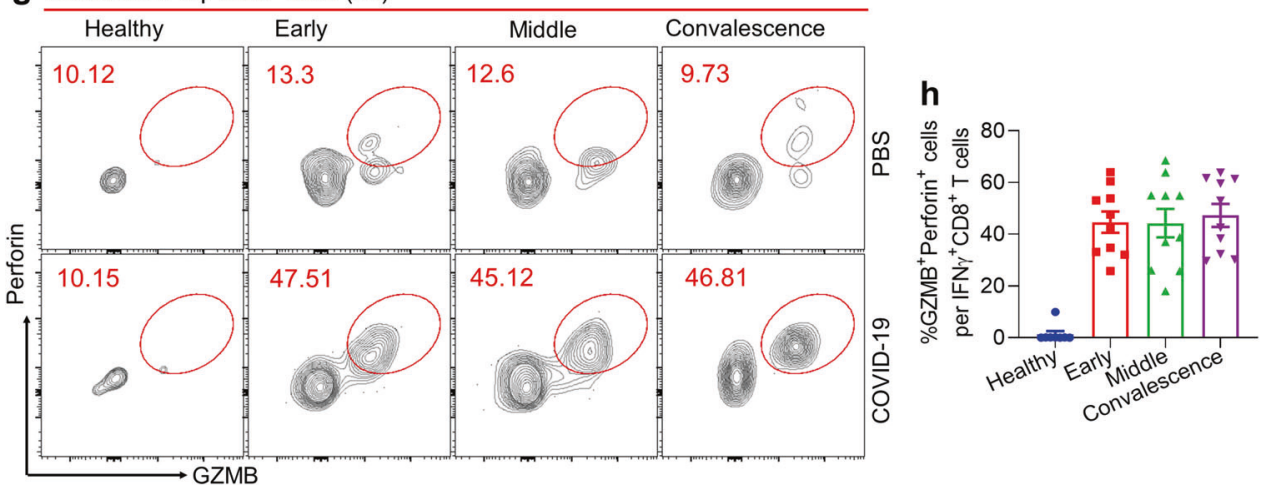

autoimmune disease, kidney or liver disease, congestive heart failure, malignancy, coagulopathy, hepatitis B or C, or HIV infection.

The 64 COVID-19 convalescent donors enrolled in the study were provided written informed consent. The blood samples of COVID-19 patients were obtained from Chongqing Public Health
Medical Center. The study received IRB approvals at Chongqing Public Health Medical Center (2020-023-01-KY).

SARS-CoV-2 S1, S2 ELISA

ELISA protocol generally followed that of precious study. ${ }^{18}$ Briefly, costar 96-well clear plates (Costar, 42592) were coated with 
Fig. 5 Kinetics of SARS-CoV2 specific CD4 ${ }^{+}$and $C D 8^{+}$T cell responses in COVID-19 asymptomatic patients. PBMCs of healthy control $(n=8)$ and asymptomatic COVID-19 patients $(n=10)$ were stimulated with SARS-CoV-2 dominant antigen (S1, S2, and nucleoprotein, N) cocktails for $44 \mathrm{~h}$, Golgi-Plug containing Golgi-stop and DNAase were added into cell culture for another $4 \mathrm{~h}$. Representative samples were from Healthy (\#3), Asymptomatic (\#3). a FACS plot examples of IFN $\gamma^{+} \mathrm{CD}^{+}{ }^{+} \mathrm{T}$ cells in total live CD4 ${ }^{+} \mathrm{T}$ cells, gated on total live CD4 ${ }^{+} \mathrm{T}$ cells. b Bar graph shows the frequency of IFN $\gamma^{+} \mathrm{CD}^{+} \mathrm{T}$ cells in total $\mathrm{CD} 4^{+} \mathrm{T}$ cells after stimulation, summarized from (a). c FACS plot examples of $\mathrm{GZMB}^{+}$Perforin ${ }^{+} \mathrm{CD} 4^{+} \mathrm{T}$ cells in total IFN $\gamma^{+} \mathrm{CD}^{+}{ }^{+} \mathrm{T}$ cells, gated on total live IFN $\gamma^{+} \mathrm{CD}^{+}{ }^{+}$cells. d Frequency of $\mathrm{GZMB}^{+} \mathrm{Perforin}^{+} \mathrm{CD} 4^{+} \mathrm{T}$ cells in total IFN $\gamma^{+} \mathrm{CD}^{+} \mathrm{T}$ cells, summarized from (c). e FACS plot examples of IFN $\gamma^{+} \mathrm{CD} 8^{+} \mathrm{T}$ cells in total live $\mathrm{CD} 8^{+} \mathrm{T}$ cells, gated on total live $\mathrm{CD} 8^{+}$ $\mathrm{T}$ cells. $\mathbf{f}$ Bar graph shows the frequency of IFN $\gamma^{+} \mathrm{CD}^{+} \mathrm{T}$ cells in total $\mathrm{CD} 8^{+} \mathrm{T}$ cells after stimulation, summarized from (e). $\mathbf{g}$ FACS plot examples of $\mathrm{GZMB}^{+}$Perforin ${ }^{+} \mathrm{CD}^{+} \mathrm{T}$ cells in total IFN $\gamma^{+} \mathrm{CD} 8^{+} \mathrm{T}$ cells, gated on total live IFN $\gamma^{+} \mathrm{CD} 8^{+} \mathrm{T}$ cells. $\mathbf{h}$ Frequency of $\mathrm{GZMB}^{+}$Perforin ${ }^{+} \mathrm{CD}^{+} \mathrm{T}$ cells in total IFN $\gamma^{+} \mathrm{CD}^{+} \mathrm{T}$ cells, summarized from (g). Bars represent the mean $\pm \mathrm{SEM}$. $P$ values were calculated based on Bonferroni of one-way ANOVA analysis. There was no statistically significant difference among different stage of asymptomatic patients

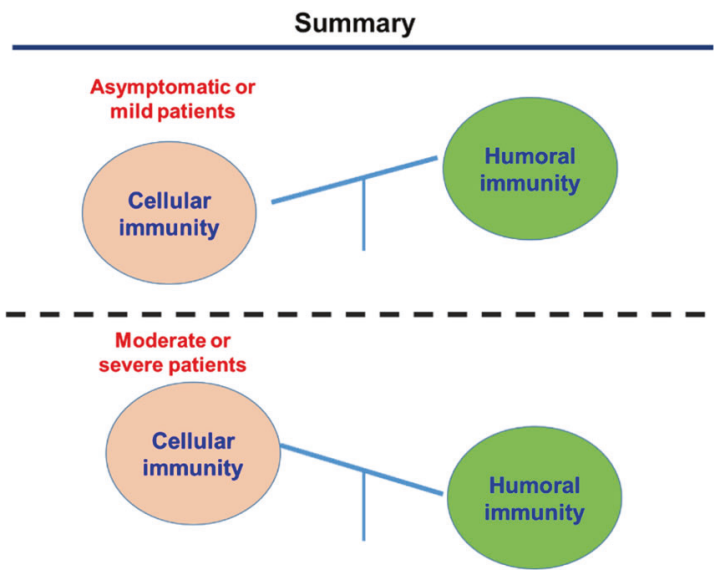

Fig. 6 Schematic summary of adaptive immunity of COVID-19 patients with different disease severity. (Up panel) Patients of asymptomatic or mild disease mount a predominant cellular immunity but low to no humoral immunity. (Lower panel) Patients of moderate or severe disease induce a potent humoral immunity, while fail to elicit an effective cellular immunity

$500 \mathrm{ng} / \mathrm{mL}$ SARS-CoV-2 S1 protein (Sino Biological, 40591-V08H) or SARS-CoV-2 S2 protein (Sino Biological, 40590-V08B) overnight at $4{ }^{\circ} \mathrm{C}$. The next day, plates were blocked with $100 \mu \mathrm{L}$ blocking buffer (5\% FBS and $0.1 \%$ Tween 20 in PBS) at room temperature for $2 \mathrm{~h}$. After washing with PBST buffer (0.1\% Tween 20 in PBS), 1:100 diluted serum was then added to the plates and incubated for $1 \mathrm{~h}$ at room temperature. Serum was diluted in blocking buffer. Serum was heat inactivated at $56^{\circ} \mathrm{C}$ for $30 \mathrm{~min}$ before added to the plate. Then, these plates were washed 5 times with $0.05 \%$ PBSTween 20. Then these ELISA plates were incubated with antihuman IgG HRP antibody (Bioss Biotech, 0297D) at room temperature for $1 \mathrm{~h}$. Anti-human IgG antibody was used at a 1:3000 dilution. Then, these plates were washed 5 times with 0.05\% PBS-Tween 20 and $100 \mu \mathrm{L}$ TMB buffer (Beyotime, P0209) was added and reacted for $15 \mathrm{~min}$ at room temperature. These reactions were stopped with $1 \mathrm{M} \mathrm{H}_{2} \mathrm{SO}_{4}$ stopping buffer. Plates were read on a Beckman Coulter Plate Reader at $450 \mathrm{~nm}$, and ODs were background subtracted.

\section{CXCL13 ELISA}

The costar 96-well clear plates (Costar, 42592) were coated with $2 \mu \mathrm{g} / \mathrm{mL}$ CXCL13 monoclonal antibody (Sino Biological, 70057MM13) overnight at $4{ }^{\circ} \mathrm{C}$. The next day, plates were blocked with $100 \mu \mathrm{L}$ blocking buffer (5\% FBS and $0.1 \%$ Tween 20 in PBS) at room temperature for $2 \mathrm{~h}$. After washing with PBST buffer $(0.1 \%$ Tween 20 in PBS), heat-inactivation serum was then added to the plates and incubated for $2 \mathrm{~h}$ at room temperature. Then, these plates were washed 5 times with $0.05 \%$ PBS-Tween 20. Then these ELISA plates were incubated with $2 \mu \mathrm{g} / \mathrm{mL}$ CXCL13 polyclonal antibody (Sino Biological, 70057-RP01) for $2 \mathrm{~h}$ at room temperature. These plates were washed 5 times with 0.05\% PBSTween 20. Then incubated with goat anti-rabbit lgG HRP antibody (Sigma) at room temperature for $1 \mathrm{~h}$. Anti-rabbit lgG antibody was used at a 1:3000 dilution. Then, these plates were washed 5 times with $0.05 \%$ PBS-Tween 20 and $100 \mu \mathrm{L}$ TMB buffer (Beyotime, P0209) was added and reacted for $15 \mathrm{~min}$ at room temperature. These reactions were stopped with $1 \mathrm{M} \mathrm{H}_{2} \mathrm{SO}_{4}$ stopping buffer. Plates were read on a Beckman Coulter Plate Reader at $450 \mathrm{~nm}$, and ODs were background subtracted.

\section{PBMC isolation and serum collection}

Whole blood in micro-anticoagulant tube was centrifuged for $15 \mathrm{~min}$ at $2200 \mathrm{rpm}$ at room temperature to separate the cellular fraction. Peripheral blood mononuclear cells (PBMCs) were isolated by density-gradient sedimentation using Ficoll-Paque (Haoyang Biological, Tianjin, China). Briefly speaking, blood 1:1 diluted with PBS, was gently layered over an equal volume of Ficoll in a $15 \mathrm{ml} \mathrm{BD}$ centrifuge tube and centrifuged for $25 \mathrm{~min}$ at $2200 \mathrm{rpm}$ without brake. There were four layers, the second layer contained PBMCs. These cells could be gently removed using a Pasteur pipette and added to PBS to wash off any remaining platelets. Isolated PBMCs were cryopreserved in cell recovery media (90\% heat inactivated fetal bovine serum and 10\% DMSO, Gibco) and stored in liquid nitrogen until used in the assays. The serum was carefully removed from blood without sodium citrate treatment and stored at $-80^{\circ} \mathrm{C}$.

SARS-CoV2 recombinant protein S1/S2 biotinylation

For biotinylation, SARS-CoV2 recombinant protein S1/S2 added to a final concentration of $150 \mathrm{ng} / \mu \mathrm{L}$, Biotin was added to $50 \mu \mathrm{M}$. After fully mixed, the reaction was proceeded on ice for $2 \mathrm{~h}$. Biotinylated proteins were desalted using $\mathrm{Zeba}^{\mathrm{TM}}$ Spin Desalting Columns 7K MWCO (Cat \#89882, Thermo Fisher) according to the manufacturer's instruction. Then we confirmed the biotinylation of S1/S2 using dot blotting assay.

\section{Surface staining and flow cytometry}

Cryopreserved PBMCs were thawed and rested in $10 \mathrm{ml}$ complete RPMI 1640 with $10 \%$ human $A B$ serum (Gemini Bioproducts) at $37^{\circ} \mathrm{C}$ for $3 \mathrm{~h}$. PBMCs were washed with FACS buffer (PBS plus $2 \%$ FBS, Gibco), and then Fc blocking reagent (Meltenyi Biotec) was added for $15 \mathrm{~min}$ at room temperature, followed by three times wash with FACS buffer. Cells were then incubated for 30 min on ice with corresponding antibodies or Biotinylaed S1/S2 proteins. Antibodies used in the T cell and B cells surface marker staining are listed in Table S4. Then washed three times with FACs and acquired by FACS Verse (BD Biosciences, San Jose, CA). Data were analyzed by FlowJo software (Version 10.0.8, Tree Star Inc., Ashland).

Intracellular cytokine staining and flow cytometry

PBMCs in wells of a 96-well plate with $100 \mu \mathrm{L}$ complete RPMI 1640 and $10 \%$ human $A B$ serum (Gemini Bioproducts) and PenStrep, were incubated $44 \mathrm{~h}$ with $1 \mu \mathrm{M}$ of recombinant proteins 
(S1, S2, and nucleoprotein, N) or were incubated $14 \mathrm{~h}$ with $100 \mathrm{ng} / \mathrm{ml}$ of SARS-CoV-2 specific peptides ${ }^{10}$ (Table S3). GolgiPlug containing Golgi-stop (BD Biosciences, San Diego, CA) and DNase (Sigma, USA) with or without $1 \mu \mathrm{g} / \mathrm{mL}$ lonomycin plus $50 \mathrm{ng} / \mathrm{mL}$ phorbol 12-myristate 13-acetate (PMA) were added another $4 \mathrm{~h}$ into the culture. A stimulation with an equal amount of PBS was used as negative control. PMA plus ionomycin were included as positive controls. Cells were then washed with FACS buffer and surface stained for $30 \mathrm{~min}$ on ice, then fixed and permeabilizated with BD Cytofix/Cytoperm solution (BD, Cat\#554722) for $30 \mathrm{~min}$ at $4^{\circ} \mathrm{C}$, followed by washing with perm/wash buffer (BD) and intracellular stained for 30 min on ice. Antibodies used in this assay were listed in Table S4. The gates applied for the identification of Perforin, GZMB and IFNY positive cells were defined according the cells cultured with PBS for each sample. All samples were acquired on a BD FACSymphony cell sorter (BD Biosciences, San Diego, CA).

Quantification and statistical analysis

FlowJo 10 and GraphPad Prism 8.0.2 were used for data and statistical analyses. The statistical detail information of the experiments was provided in the respective Figure legends. Correlation analyses were performed using Spearman and Mann-Whitney tests were applied for unpaired comparisons. One-way analysis was performed for more than two-group analysis. $P$ values less than 0.05 were considered to be statistically significant. $P$ values in Figs. 1-4 were summarized in Table S2.

\section{DATA AVAILABILITY}

This data sets of the study are available from the corresponding authors upon reasonable request.

\section{ACKNOWLEDGEMENTS}

This work was supported by grants from the National Key Research Development Plan (No. 2016YFA0502202 to L.Ye), the National Science and Technology Major Project (No. 2017ZX10202102-006-002 to L.Y.), the National Natural Science Fund for Distinguished Young Scholars (No. 31825011 to L.Y.) and the Chongqing Special Research Project for Novel Coronavirus Pneumonia Prevention and Control (No. cstc2020jscx-2 to L.Y.; No. cstc2020jscx-fyzx0074 to Y.C.; ocstc2020jscx-fyzx0135 to Y.C.).

\section{AUTHOR CONTRIBUTIONS}

L.G., J.Z., S.Y., L.W., X.C., Y.Y., R.L., Z.P., J.Z., Z.L., Q.H., J.T., and L.H. performed the experiments. L.Y. designed the study, analyzed the data, and wrote the paper with L.G., J.Z., S.Y., P.L., G.Z., and Y.C.; and L.Y., G.Z., and Y.C. supervised the study.

\section{ADDITIONAL INFORMATION}

Supplementary information The online version contains supplementary material available at https://doi.org/10.1038/s41392-021-00525-3.

Competing interests: The authors declare no competing interests.

\section{REFERENCES}

1. WHO. Coronavirus disease (COVID-19) Weekly epidemiological update-24 November 2020. (2020).

2. Amanat, F. \& Krammer, F. SARS-CoV-2 vaccines: status report. Immunity $\mathbf{5 2}$ 583-589 (2020)

3. Thanh Le, T. et al. The COVID-19 vaccine development landscape. Nat. Rev. Drug Disco. 19, 305-306 (2020)

4. Raoult, D. et al. Coronavirus infections: Epidemiological, clinical and immunological features and hypotheses. Cell Stress 4, 66-75 (2020).

5. Mizumoto, K, Kagaya, K, Zarebski, A \& Chowell, G. Estimating the asymptomatic proportion of coronavirus disease 2019 (COVID-19) cases on board the Diamond Princess cruise ship, Yokohama, Japan, 2020. Euro Surveill. 25, 2000180 (2020).

6. COVID-19 Treatment Guidelines, $7^{\text {th }}$ edition (National Health Commission of the People's Republic of China, 2020).
7. Aoshi, T. et al. Innate and adaptive immune responses to viral infection and vaccination. Curr. Opin. Virol. 1, 226-232 (2011).

8. Ni, L. et al. Detection of SARS-CoV-2-specific humoral and cellular immunity in COVID-19 convalescent individuals. Immunity 52, 971-977.e973 (2020).

9. Grifoni, A. et al. Targets of T cell responses to SARS-CoV-2 coronavirus in humans with COVID-19 disease and unexposed individuals. Cell 181, 1489-1501.e1415 (2020).

10. Le Bert, N. et al. SARS-CoV-2-specific T cell immunity in cases of COVID-19 and SARS, and uninfected controls. Nature 584, 457-462 (2020).

11. Cao, Y. et al. Potent neutralizing antibodies against SARS-CoV-2 identified by high-throughput single-cell sequencing of convalescent patients' B cells. Cell 182 73-84 (2020). e16.

12. Woodruff, M. et al. Critically ill SARS-CoV-2 patients display lupus-like hallmarks of extrafollicular B cell activation. medRxiv. Preprint at https://doi.org/10.1101/ 2020.04.29.20083717 (2020).

13. Ibarrondo, F. J. et al. Rapid decay of anti-SARS-CoV-2 antibodies in persons with mild covid-19. N. Engl. J. Med. 383, 1085-1087 (2020).

14. Long, Q. X. et al. Clinical and immunological assessment of asymptomatic SARSCoV-2 infections. Nat. Med. 26, 1200-1204 (2020).

15. Zhang, Z. et al. Early viral clearance and antibody kinetics of COVID-19 among asymptomatic carriers. medRxiv. Preprint at https://doi.org/10.1101/ 2020.04.28.20083139 (2020).

16. Lee, Y. L. et al. Dynamics of anti-SARS-Cov-2 IgM and IgG antibodies among COVID-19 patients. J. Infect. 81, e55-e58 (2020).

17. Wen, W. et al. Immune cell profiling of COVID-19 patients in the recovery stage by single-cell sequencing. Cell Disco. 6, 31 (2020).

18. Chen, $X$. et al. Human monoclonal antibodies block the binding of SARS-CoV-2 spike protein to angiotensin converting enzyme 2 receptor. Cell Mol. Immunol. 17, 647-649 (2020)

19. Ho, M. Perspectives on the development of neutralizing antibodies against SARSCoV-2. Antib. Ther. 3, 109-114 (2020).

20. Huang, Q., Xu, L. \& Ye, L. T cell immune response within B-cell follicles. Adv. Immunol. 144, 155-171 (2019).

21. Pedros, C. et al. A TRAF-like motif of the inducible costimulator ICOS controls development of germinal center TFH cells via the kinase TBK1. Nat. Immuology 17, 825-833 (2016).

22. McGuire, H. M. et al. CXCL13 as a biomarker of immune activation during early and chronic HIV infection. Proc. Natl Acad. Sci. USA 10, 289 (2019).

23. Brenna, E. et al. CD4(+) T follicular helper cells in human tonsils and blood are clonally convergent but divergent from non-Tfh CD4(+) cells. Cell Rep. 30, 137-. e135 (2020).

24. Carter, M. J. et al. The antibody-secreting cell response to infection: kinetics and clinical applications. Front. Immunol. 8, 630 (2017).

25. Fink, K. Origin and function of circulating plasmablasts during acute viral infections. Front. Immunol. 3, 78 (2012).

26. Wong, C. K. et al. Plasma inflammatory cytokines and chemokines in severe acute respiratory syndrome. Clin. Exp. Immunol. 136, 95-103 (2004).

27. Mahallawi, W. H. et al. MERS-CoV infection in humans is associated with a proinflammatory Th1 and Th17 cytokine profile. Cytokine 104, 8-13 (2018).

28. Yoo, J. K., Kim, T. S., Hufford, M. M. \& Braciale, T. J. Viral infection of the lung: host response and sequelae. J. Allergy Clin. Immunol. 132, 1263-1276 (2013). quiz 1277.

29. Janice Oh, H. L., Ken-En Gan, S., Bertoletti, A. \& Tan, Y. J. Understanding the T cell immune response in SARS coronavirus infection. Emerg. Microbes Infect. 1, e23 (2012).

30. Chen, $\mathrm{H}$. et al. Response of memory CD8+ T cells to severe acute respiratory syndrome (SARS) coronavirus in recovered SARS patients and healthy individuals. J. Immunol. 175, 591-598 (2005).

31. Peng, Y. \& Mentzer, A. J. Broad and strong memory CD4(+) and CD8(+) T cells induced by SARS-CoV-2 in UK convalescent individuals following COVID-19. Nat. Immuology 21, 1336-45 (2020).

32. Rydyznski Moderbacher, C. et al. Antigen-specific adaptive immunity to SARSCoV-2 in Acute COVID-19 and associations with age and disease severity. Cell 183, 996-1012 (2020). e1019.

33. Nelde, A. \& Bilich, T. SARS-CoV-2-derived peptides define heterologous and COVID-19-induced T cell recognition. Nat. Immunol. 22, 74-85 (2020).

34. Mathew, D. \& Giles, J. R. Deep immune profiling of COVID-19 patients reveals distinct immunotypes with therapeutic implications. Science. 369, eabc8511 (2020).

35. Takeuchi, A. \& Saito, T. CD4 CTL, a cytotoxic subset of CD4(+) T cells, their differentiation and function. Front. Immunol. 8, 194 (2017).

36. Welsh, R. M. \& Selin, L. K. No one is naive: the significance of heterologous T-cell immunity. Nat. Rev. Immunol. 2, 417-426 (2002).

37. Cui, J., Li, F. \& Shi, Z. L. Origin and evolution of pathogenic coronaviruses. Nat. Rev. Microbiol. 17, 181-192 (2019). 
The dichotomous and incomplete adaptive immunity in COVID-19 patients. .

Gao et al.

(c) Open Access This article is licensed under a Creative Commons Attribution 4.0 International License, which permits use, sharing, adaptation, distribution and reproduction in any medium or format, as long as you give appropriate credit to the original author(s) and the source, provide a link to the Creative Commons license, and indicate if changes were made. The images or other third party material in this article are included in the article's Creative Commons license, unless indicated otherwise in a credit line to the material. If material is not included in the article's Creative Commons license and your intended use is not permitted by statutory regulation or exceeds the permitted use, you will need to obtain permission directly from the copyright holder. To view a copy of this license, visit http://creativecommons. org/licenses/by/4.0/.

(c) The Author(s) 2021 